\title{
Local Folklore and Reading Comprehension of Eight Grade Students at SMP N 2 Baubau
}

\author{
Fitriani $^{1 *}$ and Jumardin Muchtar ${ }^{2}$ \\ ${ }^{1,2}$ Department of English Language Studies, Universitas Hasanuddin, Makassar, Indonesia \\ *Fitrianiunesa@gmail.com
}

\begin{abstract}
The question in this research is whether using local folklore can improve reading comprehension in SMPN 2 Bau-Bau grade eight students. The goal of this study is to discover whether using local folklore can improve reading comprehension in eighth-grade students at SMPN 2 Bau-Bau. This is an experimental study, and the populations in this study were all of the grade VIII students at SMPN 2 Bau-Bau, which consists of 11 classes with a total of 275 students. The sample for this study is the VIII.7 class, which consists of 25 students as the control class, and the VIII.5 class, which consists of 2 students as the experimental class. The instrument used in this study was a test. The following research outcomes were obtained: 1) The experimental class received a mean score of 64.80 , and the posttest received a mean score of $84.00 ; 2$ ) The control class received a mean score of 51.60, and the posttest received a mean score of 69.20 .
\end{abstract}

Key words: Local folklore, reading comprehension, students.

\section{Introduction}

Reading comprehension is the ability to process a text, understand its meaning, and integrate it with what the reader already knows. However, reading comprehension is a complex process that does not occur automatically. First and foremost, the reader must be able to decode the words. As [1] stated, readers can decode the words but have not developed sufficient skills to comprehend the underlying deeper meaning of the sentences, paragraphs, and entire text. It is necessary to read the reading material aloud in order to assist the reader in decoding each word

Unfortunately, it was discovered that the students had some difficulty comprehending the narrative text. The issues arose while the researcher was teaching reading in SMPN 2 Bau-Bau. The researchers discovered that the eighth-grade students of SMP N 2 Baubau, particularly class VIII.1, were uninterested in reading lessons and had low motivation in learning because the stories frequently came from other countries and the reading text was not appropriate to the students' background knowledge. As a result, the text was difficult for the students to understand.

From the description above, it is clear that the researcher is interested in solving the problem by using local folklore as reading material. Local folklore is a type of literature that exists among the people. In general, local folklore refers to people from the past who have left an inheritance within a particular society. Local folklore is literature that has been passed down from generation to generation in a traditional society in which people have known the letters for quite some time, and which consists of survival and anonymity, and has been passed down orally for a 
long time. It can be concluded that local folklore is a legacy that should be protected because, in addition to being an inheritance, it can be used as a learning medium [2]. local folklore is a better choice for learning stories in learning transmission, particularly for reading comprehension, because students have more prior knowledge of their local stories than stories from other regions. Prior knowledge of local folklore can help students predict the meaning of words and comprehend the detailed information in narrative text [3].

\section{Theoritical Reviews}

\section{Definition of Reading Comprehension}

Some scholars provide numerous definitions of reading comprehension. Reading comprehension is a process of constructing meaning through the dynamic interaction of (a) the reader's prior knowledge; (b) the information suggested by the text being read; and (c) the context of the activity. It refers to the ability to interpret words, comprehend meaning, and understand the relationships between ideas conveyed in a text. For the teacher, she summarized reading comprehension instruction as a three-step process: mentioning, practicing, and assessing. That is, the teacher mentions the skills that the students want to use, then provides opportunities for them to practice those skills through workbooks or worksheets, and finally assesses whether or not they use the skill successfully [4]. comprehension is the process of connecting words and sentences to the text in order to make sense of them. He defines comprehension as "the process of conveying the meaning of one word to another in a text." Readers typically use background knowledge such as vocabulary, grammar, experience with the text, and other strategies to help them understand the written text [5].

Reading comprehension can be characterized by the ability to find the stated or unstated writer's idea in the text based on the definition above. The essence of reading comprehension comprehends all of the details given by the writer. It also refers to the ability to connect words in a text, to comprehend ideas and relationships between ideas in conveyed text.

\section{Types of Reading Comprehension}

Activating background knowledge is an important activity to perform when attempting to comprehend a text. Reading comprehension, as previously stated, entails the process of integrating and relating the information in the text to the reader's prior knowledge. [6] identifying three types of reading comprehension based on how readers use prior knowledge to construct meaning. The first type is what is known as "textual explicit." Readers are helped in this reading type by some clear information in the text. As a result, readers are not required to delve deeply into their prior knowledge.

The second type is what is known as "textual implicit." Readers must use their background knowledge to find out the information contained in the text in this reading type, because the information obtained from the text is insufficient to assist them in comprehending the text. The last type is what is scripturally implicit. When readers use this reading type, they must open their background knowledge deeply in order to understand the text, because information within the text is derived both explicitly and implicitly.

\section{Teaching of Reading Comprehension}

Reading is generally defined as the process of decoding text and then receiving information. It is clear from this that reading involves more than one process. Other language processes, such as listening and reading (receptive process), speaking and writing (productive process), and thinking processes, are still involved in the reading process. These are the primary processes that occur during reading. They happen when readers read the text, clarify the text, and declare the text's information. the process of reading comprehension can be classified into three types based on the order in which readers decode the language: bottom-up, top-down, and interactive reading. In the bottom-up process, readers must first be able to decode the text in order to comprehend the text, which includes the letter, the form of words, and the source of the words. In this process, readers must first be able to decode the test in order to comprehend the text [7]. Then, in the top-down process, readers must use their prior knowledge to understand the text, i.e., readers must look at the title of the text and relate it to their prior knowledge to guess what the text is about. Finally, when reading interactively, readers attempt to combine bottom-up and top-down processing. Readers not only identify and decode the text's language features, but they also use prior knowledge and experience to comprehend the text [8].

\section{How to Improve Reading Comprehension}

The goal of reading is to make connections between the ideas on the page and what you already know. If we don't know anything about a subject, reading text is akin to pouring water into our hands. We don't remember much. Similarly, 
if we enjoy sports, it is simple to read the sports page. We have a mental framework for reading, comprehending, and storing information [9]. Reading comprehension requires motivation, mental frameworks for holding ideas, concentration and good study techniques. Here are some suggestions:

\section{Develops broad background}

Boarden our background knowledge by reading newspapers, magazines and books. Become interested in world events.

\section{Know the structure of pharagraphs}

Good writers construct paragraphs that have a beginning, middle and end. Often, the first sentences give an overview that helps provide a framework for adding details. Also for transitional words phrases paragraphs that changed the topic.

\section{Identify the type of reasoning}

Does the author use cause and effect reasoning, hyppotesis, model building, deduction and systems thinking?

\section{Anticipate and predict}

Really smart readers try to anticipate the author and predict the future ideas and questions. If we're right. This reinforeces our understanding. If we're wrong, we make adjustments quicker.

\section{Narrative Text}

Narrative text has three generic lexico grammatically structural elements. They are as follows: orientation, complication, and resolution. Orientation is the first of these. This is a segment from the first story [10]. As stated in the opening story, creating an interesting story is critical in order to pique the reader's interest and entice them to read further. It should also explain the story's background, such as setting the mood by defining the setting, time, and the main character, the relationship between the characters, and other information to give the reader a place to start [11].

The second is complications, which is the story's main body. This section contains an event that causes the characters to become involved in a complication when normal events are disrupted by some form of conflict. There may be more than one complication that frustrates the characters in their attempts to achieve their goals. The reader will feel tension and anticipation as a result of this. The final step is resolution. For better or worse, the crisis is over. This section concludes the character's problems and conflicts. There are three options for resolution. First and foremost, the story will conclude with a happy ending. Finally, the author lets the reader guess how the story will end.

\section{Definition of Local Folklore}

Local folklore refers to folklore that exists in or belongs to the area where you live, or the area where you live, or the area about which you are speaking. Local folklore is a type of literature that exists among the people. Local folklore, in general, refers to the people of the past who have become an inheritance in society. Local folklore is a type of literature that has been passed down from generation to generation in traditional societies, and it has consisted of survial, anonim, and oral transmission for a long time [12].

\section{Oral Folklore (verbal folklore)}

Oral folklore is entirely oral. This large group's folklore forms (genres) include (a) folk speech, such as accents, nicknames, traditional ranks, and titles of nobility; (b) traditional expressions, such as language, maxim, and reply; (c) traditional questions, such as puzzles; (d) people's poetry, such as rhymes, gurindam, and poetry; Myths, legends, and fairy tales are examples of folk prose stories.

Partially oral folklore (partly verbal folklore). Partially oral folklore, also known as partly verbal folklore, is a type of folklore that combines oral and nonverbal elements. For example, superstition, as defined by the "modern" person, consists of oral statements combined with gestures that are supposed to have supernatural meanings, such as the sign of the cross for Catholic Christians, which is supposed to protect a person from a ghostly disorder, and material objects that are thought to be efficacious in protecting themselves or bringing fortune, such as certain gemstones. In addition to popular beliefs, folklore forms include people's games, folk theater, folk dance, people's customs, ceremonies, festivals, and so on.

Non-verbal folklore. Non-verbal folklore is folklore in which the form is not oral but in which the method of production is taught orally. This broad category can be divided into two subcategories: material and non-material. Folklore forms associated with the material include folk architecture (original house form, rice bran form, and so on), people's crafts, custom body clothes and jewelry, folk foods and drinks, and traditional medicines. Traditional gestures, customary 
sounds for people's communications (such as a jolt of alarm in Java or drumming to send news, as done in Afrika), and folk music are also non-material items.

\section{Function of Folklore}

Folklore's function, in addition to entertaining people, can increase knowledge, educate children, give advice, and mandate, because people who tell essentially want to convey a message or a mandate that is beneficial to the character and personality of the listener for the younger generation [14]. Folklore is one of Indonesia's cultural heritages, and it must be preserved in order to be sustainable

\section{Methodology}

\section{Design Research}

This research is designed in a quasi-experimental manner. A quays experimental design is a research design that involves selecting groups on which a variable is tested without using any random pre-selection processes. The non-equivalent control group design used two groups, one of which received treatment and the other of which did not or was not conventional. Both groups received a pre-test and a post-test; the pre-test was used to determine the students' prior knowledge, and the post-test used to determine the students' progress in reading comprehension [15]. The design created as follows:

$\begin{array}{llll}\text { EG } & \mathrm{O}_{1} & \mathrm{X} & \mathrm{O}_{2} \\ \text { CG } & \mathrm{O}_{3} & \mathrm{X} & \mathrm{O}_{4}\end{array}$

Where :

EG : Experimental Group; $O_{1}$ : pre-test; $\mathrm{X}$ : treatment; $\mathrm{O}_{2}$ : post-test; $\mathrm{O}_{3}$ : pre-test; $\mathrm{CG}$ : Control Group

$\mathrm{O}_{4}$ : post-test

\section{Population and Sample}

\section{Population}

The eighth-grade students at SMPN 2 Bau-Bau are the study's population. There are 11 classes with a total of 275 students in them. Which had 25 students in each class. The eighth-grade students at SMP N 2 Bau-Bau are study's population. There are 11 classes with a total of 275 students in them, which have 25 students in each class.

\section{Sample}

Because the population considered homogeneous, the sampling technique used in this study is cluster random sampling. Furthermore, [16] states that if the scope of the research is too broad, cluster random sampling is used to determine sample size. Sampling is the process of selecting a group of people for a study in such a way that the people chosen represent the larger group from which they were drawn. The samples were drawn from two classes of eighth-grade students at SMPN 2 Bau-Bau. They are in classes VIII.5 as an experiment and VIII.7 as a control. The total number of samples is 50 students.

\section{Instrument of The Research}

The research instruments are put to the test. It was used to see if there are any significant differences in students' reading comprehension when using narrative text from local folklore while learning English. There are two parts to the test: a pretest and a posttest. In this case, a pretest is administered prior to treatment to assess students' prior knowledge, and a posttest was administered following treatment to assess the treatment effect.

\section{Technique Data Collection}

Technique of Data Collection in Experiment Class:

\section{Pre-Test}

At the first meeting, the researcher administered a pretest to determine the students' reading comprehension before employing local folklore by exploring the students' knowledge of the material that will be presented, also known as apperception. The researcher uses the story "Loke Nggerang," which was about a story from the outside region of Nusa Tenggara Barat. The researcher asked the students to answer five multiple-choice questions so that the researcher could determine whether there was a significant difference after using local folklore. 


\section{Treatment}

After getting the result of the pretest, the researcher gives the treatment to the students by applying local folklore. It conducted during four meetings with the following procedures:

Meeting 1. At this meeting, the researcher gives greetings to the students and checked the students' attendance lists. After that, the researcher gave information about the objective of the learning activity. The researcher shares a local folklore text with the title "Pasikamba" and asked the students about their background of knowledge or gave stimulation about the story to know how far the students knew about their own stories in their region. They also asked some students to read it and the others tried to comprehend it after the researcher.

Meeting II. During this meeting, the researcher greets the students and checked the students' attendance list, after which the researcher explains the purpose of the learning activity. The researcher explains generic narrative text structures to the students in the second meeting. There are three of them: orientation, complications, and resolution. Orientation explains the story's subjects, time, and place. Complication is about explaining the story's problems, and resolution was about the story's conclusion or mandate. After explaining the generic structures, the researcher instructed the students to analyze the story based on narrative text structure using the English language and answer five multiple-choice questions.

Meeting III. The researcher greets the students and checked the students' attendance list, after which the researcher explains the purpose of the learning activity. The researcher asks the students to retell local folklore in front of the class that has previously been read in another structured activity or first meeting. Again, the students are instructed to respond to the analysis results and five multiple-choice questions from the local folklore text, as well as questions about the materials that they do not understand.

Meeting IV. The researcher greets the students and checks the students' attendance list before providing information about the learning activity's objectives. At the end of the treatment, the researcher reviews the material and interviews the students about the use of local folklore in the learning process, and the results shows that students are very enthusiastic about using their local folklore.

\section{Post Test}

The researcher administers a test to determine the students' reading comprehension in the post-test by presenting them with various texts. The title was "Bone Malei." The researcher instructs the students to answer a series of five multiple-choice questions in order to determine whether there is a significant difference between before and after the use of local folklore.

\section{Technique of Data Analysis}

Data analysis is the process of arranging data sequences, organizing them into a system, categorizing them, and determining their basis. Both descriptive and inferential statistics are used to determine whether or not there is a significant difference in students' reading comprehension in learning English in the research group when analyzing data about eighth grade students in SMPN 2 Bau-Bau. The researcher employs the following technique in data processing:

\section{Pre-Requirement Analysis}

Test Normality. Test of normality is used to know the sample have normal distribution or not. Normality test that the researcher uses in this research was Shapiro-Wilk test with SPSS.

1. If the value (p) $\geq$ significant $(\alpha=0,05)$ it means that the sample from the population, $H_{0}$ is accepted and $H_{1}$ is rejected (normal distribution)

2. If the value $(p) \leq$ significant $(\alpha=0,05)$ it means $H_{0}$ is rejected and $H_{1}$ is accepted (not normal distribution)

Table 1. Test Normality Result

\begin{tabular}{lll}
\hline \multicolumn{3}{c}{ Shapiro-Wilk } \\
\hline Stastistc & Df & Sig. \\
\hline, 933 & 50 &, 007 \\
, 926 & 50 &, 004 \\
\hline
\end{tabular}


Based on the table of test normality result it shown that the value (p) or Sig is $007 \geq$ significant $(\alpha=0,05)$. It means that the sample fro the population, $H_{0}$ was accepted and $H_{1}$ was rejected(normal distribution).

Test of Homogenity. The homogeneity test is used to determine whether or not the variances in the sample were the same. The researcher uses SPSS to determine variance homogeneity (Levene test). This test was used to calculate the variance using the same probability/significance criteria: Ho is accepted if the P value was greater than 0.05 , and $\mathrm{Ho}$ is rejected if the $P$ value is less than 0.05 .

Table 2. Test Homogeneity of Variances

\begin{tabular}{llll}
\hline Levene Statistic & $\mathrm{df} 1$ & $\mathrm{df} 2$ & Sig. \% \\
\hline, 977 & 5 & 44 &, 442 \\
\hline
\end{tabular}

Based on the table test homogeneity of variances result, the value (p) or Sig is $007 \geq$ significant (. It means that the sample from the population, Ho, is accepted.

\section{Descriptive Statistic and Inferential Statistic}

Descriptive Statistic. Descriptive statistics are required to indicate general tendency (mean, mode, and median) and the spread of scores (variance, standard deviation, and range). Aside from that, descriptive statistics are used to display the minimum and maximum score [17].

1. Calculating the score of students' test by using the following formula:

$$
\text { Astudent'sscore }=\frac{\text { Thegainscore }}{\text { Maximumscore }} \times 100
$$

Table 3. Scoring Criteria (Direktorat Jenderal Pendidikan Dasar dan Menengah (2015: 62))

\begin{tabular}{lclc}
\hline No & Scoring Range & Criteria & Score in Letter \% \\
\hline 1. & $86-100$ & Very Good & A \\
2. & $71-85$ & Good & B \\
3. & $56-70$ & Moderate & C \\
4. & $\leq 55$ & Low & D \\
\hline
\end{tabular}

2. Calculating of Students' pre and post-test percentage by using the following formula :

$$
x=\frac{f}{n} \times 100 \%
$$

Where :

$x$ : Mean score

$f$ : The total frequency score

$N$ : The total number of sample

Inferential Statistic. inferential statistics as a statistical technique used to analyze sample data and then apply the results to the population. This type of statistic is appropriate to use if the sample is drawn from a clearly defines population and the method used to draw the sample from the population is random [18]. In this research, the hypotheses will be tested using a paired-sample test on a Windows version of the SPPS 15.0 program. In this study, the analysis criteria received a significance value of 0.05 to test a hypothesis.

$1 H_{0}$ is accepted if the probability value (sig. (2-tailed)) was greater than 0.05 . This means that the use of local folklore does not improve the reading comprehension of SMPN 2 Bau-Bau eighth-grade students.

2 If the probability value, sig. (2-tailed) 0.05, was accepted, H1 was accepted. It means that using local folklore improves the reading comprehension of eighth-grade SMP N 2 Bau-Bau students.

\section{Findings and Discussion}




\section{Findings}

The researcher presented the data for the pretest and posttest from the experiment group and control group, as well as the test results, in the findings of this study. All of the data was processed using SPSS 15.0, both descriptively and inferentially. The data was presented descriptively in terms of mean, median, mode, standard deviation, minimum, maximum, and sum. The data presented inferentially was in the form of a hypothesis test.

\section{Distribution of Frequency of Pre-test in Experimental and Control Group}

Table 4. Distribution of Frequency of Pretest in Experimental and Control Group

\begin{tabular}{llccccc}
\hline & & \multicolumn{2}{c}{ Experiment Group } & & \multicolumn{2}{c}{ Control Group } \\
\cline { 3 - 4 } No & Interval & Frequency & $\%$ & & Frequency & $\%$ \\
\hline 1. & $86-100$ & 0 & $0 \%$ & & $0 \%$ \\
2. & $71-85$ & 2 & $8 \%$ & & $0 \%$ \\
3. & $56-70$ & 21 & $84 \%$ & & 10 & $40 \%$ \\
4. & $\leq 55$ & 2 & $8 \%$ & & 15 & $60 \%$ \\
\hline & Total & 25 & $100 \%$ & 25 & $100 \%$ \\
\hline
\end{tabular}

According to the table above, the frequency of pretest students' reading comprehension achievement in the experimental group showed that there were no students $(0 \%)$ in the low category, 2 students $(8 \%)$ in the moderate category, 21 students $(84 \%)$ in the low category, and 2 students $(8 \%)$ in the moderate category. There were no students with low scores in the experiment group, and 23 students ( 88 percent) had moderate scores.

While the data description of the frequency of pretest students' reading comprehension achievement in the control group shows that there are not students $(0 \%)$ in the low category, no students $(0 \%)$ in the moderate category, 10 students (84\%) in the low category, and 15 students $(60 \%)$ in the low category. It is possible to conclude that no students received low-scoring results. The histogram could be represented as follows

\section{Distribution of Frequency of Post-test in Experimental and Control Group}

Table 5. Distribution of Frequency of Posttest in Experimental and Control Group

\begin{tabular}{llccccc}
\hline & & \multicolumn{2}{c}{ Experiment Group } & & \multicolumn{2}{c}{ Control Group } \\
\cline { 3 - 4 } No & Interval & Frequency & $\%$ & & Frequency & $\%$ \\
\hline 1. & $86-100$ & 9 & $36 \%$ & & $8 \%$ \\
2. & $71-85$ & 14 & $56 \%$ & & 5 & $20 \%$ \\
3. & $56-70$ & 2 & $8 \%$ & & 1 & $4 \%$ \\
4. & $\leq 55$ & 0 & $0 \%$ & & 1 & $4 \%$ \\
\hline & Total & 25 & $100 \%$ & & 25 & $100 \%$ \\
\hline
\end{tabular}

Based on the data distribution of the frequency of post-test students' reading comprehension achievement in the experimental group, 9 students (36\%) were in the high category, 3 students $(36 \%)$ in the moderate category, 2 students $(2 \%)$ in the low category, and no student $(0 \%)$ in the low category. It is possible to conclude that 9 students $(100 \%)$ received a score in the high category.

\section{Discussion}

Based on the results of the research, there was no significant difference in students' reading comprehension achievement between students taught with and without local folklore in the eighth grade students of SMP N 2 Bau-Bau. Students' reading comprehension skills improved as they were taught with local folklore. It was because reading local folklore was a good habit with a lot of educational value. The use of local folklore provides students with authentic reading resources, allowing them to emotionally connect with the text and become personally involved. Working with local folklore was not only enjoyable, but it also provided information about local history. The following are some of the benefits of reading local folklore: The students were enthusiastic and valued their local stories and wisdom; they also learned how to develop their local character. 
Folklore's function, aside from entertaining people, is to increase knowledge, educate children, and give advice and mandates to people who essentially want to convey a message or a mandate that is beneficial to their character and personality. Folklore is part of Indonesia's cultural heritage, and as such, it must be preserved in order to be sustainable. It is based on the words of a researcher. Local folklore is a type of literature that is common among the people. In general, local folklore refers to people from the past who have become an inheritance in a particular society. Local folklore is an important part of the moral values and cultural life of the elderly. local folklore is a body of literature that has been living and developing from generation to generation in a traditional society where the people have known the letters or yet, which consists of survival and anonim, and has been spread orally for a long time [19].

\section{Conclusion}

The use of local folklore material improves the students' reading comprehension in learning English, especially in joining the reading class. The students became interested in English through the use of local folklore materials. Based on the data statistic result (inferential statistic result independent test), the able showed the sig. (2-tailed) was 0.0000 .05 , so $H_{1}$ was accepted and $H_{0}$ was rejected. It could be indicated that students' teaching with local folklore was better or improving.

\section{References}

[1] A. Mohammadi and M. Davarbina, "The effect of cooperative learning techniques on reading comprehension ability of Iranian EFL learners." International J. Soc. Sci. \& Education, 5(3), 525-531. 2015.

[2] W. Surya, F Rahman and M. Makka, "Folktale from England to Toraja". Imperial Journal of Interdisciplinary Research (IJIR), 3, 2454-1362. 2017.

[3] F. Laeli, "Nilai-nilai Sosial Cerita Rakyat”. UMP. 2012

[4] S.P. Elizabeth, M. Angaluki, B. Elizabeth. Berndardt and L. Michael, Kamil, Teaching Reading. Bureau: International Bureau of Education. 2003.

[5] Y. Alberti, "Improving Students' Reading Comprehension on Narrative Texts by Using Story Grammar Strategy." Bengkulu Tengah: Bengkulu University. 2014

[6] W. Grabe, "Reading in Second Language" Cambridge University Press. (2009).

[7] M. Sitti, "Improving Reading Comprehension Through Pictures-Stories." Abstract of Surakarta Research. Surakarta: Iain Surakarta. 2015.

[8] D. Klop, "The Relation between narrative skills and Reading Comprehension." University of Stellenboch: Department of General Linguistic. 2011.

[9] Y. Dita, "Improving the English Reading Comprehension Ability." Abstract of Yogyakarta research. Yogyakarta: Yogyakarta University. 2014.

[10] W. Safitri, "Improving Reading Comprehension through Short Story." Baubau : Dayanu Ikhsanuddin University.2017

[11] S. Rini, "Fungsi Teks Narrative dalam Bahasa Inggris." A.Z Bahasa Inggris. 2018

[12] U.S.L. Markus, "Improving Students Ability in Reading Narrative text by Using Folkltale (Local Legend)." Tanjungpura: Tanjung Pura University. Presented by Annual International on Etchics, Sprituality and Morality New Delhi. 2012.

[13] F.D.M. Wijayanti, "Literature and Culture 1 (1-6)." Pontianak, West Kalimantan Indonesia : ADRI International Journal of Language Publishing. 2017.

[14] Danandjaja, James, Folklor Indonesia, Jakarta: Grafitipers. 1986.

[15] N. David, "Language Teaching Methodology." London: Prentice Hall International. 2003

[16] Panduan penulisan Skripsi. Baubau: Dayanu Ikhsanuddin University. 2012.

[17] English Speeches. Muniba Mazari Speech: We all are Perfectly Imperfect [Online]. Available: https://www . englishspeecheschannel.com/english-speeches/muniba-mazari-speech/ 